CASE NOTE

\title{
TOKYO HIGH COURT, JUDGMENT, HEISEI 30 NEN (GYOU-KO), No 232 (29 JANUARY 2020)
}

\author{
OSAMU ARAKAKI* AND WAWINE WAWORUNTU YAMASHITA**
}

TABLE OF CONTENTS

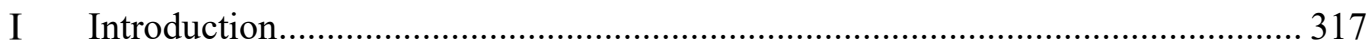

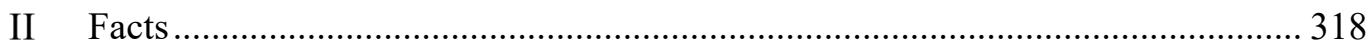

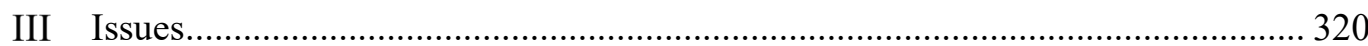

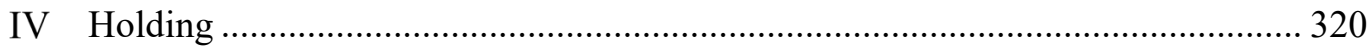

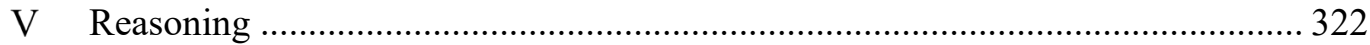

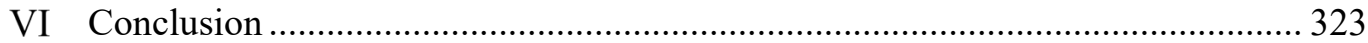

\section{INTRODUCTION}

Japan is a party to the Convention Relating to the Status of Refugees ('Refugee Convention') ${ }^{1}$ and its Protocol Relating to the Status of Refugees ('1967 Protocol'), ${ }^{2}$ but it has not acceded to the Convention Relating to the Status of Stateless Persons ('1954 Convention'), which addresses the protection of stateless persons. ${ }^{3}$ Thus, stateless persons in Japan can seek international protection through, inter alia, recognition of their refugee status, but only if they qualify as refugees. ${ }^{4}$ The case of Heisei 30 Nen (Gyou-ko) No 232 is a recent decision of the Tokyo High Court involving the recognition of refugee status where statelessness was an essential consideration. The Tokyo High Court's judgment in this case was not subsequently appealed to the Supreme Court of Japan, making the decision final and binding.

This decision is unique. Unlike the majority of judicial asylum cases in Japan, it demonstrated how the implications of statelessness can be relevant in determining whether a person meets the definition of 'refugee' provided in the Refugee Convention. It is hoped that the ruling of the court will contribute to the jurisprudence concerning protection of stateless persons under the Refugee

* Osamu Arakaki is professor of international law at International Christian University, Tokyo.

** Wawine Waworuntu Yamashita is a member of the Study Group for Statelessness, Tokyo.

1 Convention Relating to the Status of Refugees, opened for signature 28 July 1951, 189 UNTS 150 (entered into force 22 April 1954) ('Refugee Convention').

2 Protocol Relating to the Status of Refugees, opened for signature 31 January 1967, 606 UNTS 267 (entered into force 4 October 1967) ('1967 Protocol’).

3 Convention Relating to the Status of Stateless Persons, opened for signature 28 September 1954, 360 UNTS 117 (entered into force 6 June 1960).

4 A limited number of judicial asylum decisions in Japan have considered statelessness as an integral factor. These decisions show that stateless persons can be protected under the Refugee Convention (n 1) if they are refugees, but they are not protected only for being stateless. In the decisions, the relevant state in the determination of refugee status is the state of former habitual residence of the applicants rather than the state of nationality. Osamu Arakaki, 'Statelessness Conventions and Japanese Laws: Convergence and Divergence' (Study UNHCR March 2015) $78<$ https://www.unhcr.org/jp/wpcontent/uploads/sites/34/protect/Statelessness_Conventions_and_Japanese_Laws_EN.pdf>. 
Convention, and it should be of particular interest to other states that are parties to the Refugee Convention but not to the 1954 Convention. ${ }^{5}$

The case involves an applicant for refugee status who is an ethnically Armenian man, born in Georgia in 1967. He entered Japan in 2010 with a forged passport and applied for refugee status. He claimed that he is a stateless person and has a fear of persecution in Georgia, the state of his former habitual residence. ${ }^{6}$ An administrative disposition ${ }^{7}$ in 2011 denied recognition of his refugee status and the Minister of Justice gave the following reasons for the decision: the applicant had not been arrested or detained in the past in Georgia, and the government of Georgia respects the rights of ethnic minorities. ${ }^{8}$ In 2014, an administrative review of the 2011 disposition upheld the denial of his application for the same reasons given in the first instance and gave additional reasons. ${ }^{9}$

In 2015, the case was brought to the Tokyo District Court seeking to revoke the disposition of the defendant. That is, Japan (the Minister of Justice and others), denying recognition of the plaintiff's refugee status. At the Tokyo District Court, the plaintiff asserted that he is a stateless refugee who would face a risk of persecution upon his return to Georgia, the state of his former habitual residence, due to his Armenian ethnicity. ${ }^{10}$ The defendant argued that the claimed experience of the plaintiff in Georgia did not amount to persecution and that there was a lack of objective evidence showing that ethnic Armenians in Georgia were, as a group, subject to oppression in general. ${ }^{11}$ The court accepted the argument of the defendant and denied the plaintiff's petition. ${ }^{12}$ Thereafter, the plaintiff brought the case to the Tokyo High Court again seeking to revoke relevant dispositions. ${ }^{13}$

\section{FACTS}

The plaintiff's father was an ethnic Armenian and a national of the former Soviet Union. ${ }^{14}$ His mother was also a national of the former Soviet Union and Russia. ${ }^{15}$ After marriage, the two were living in Tbilisi, the capital of the Soviet Socialist Republic of Georgia. ${ }^{16}$ In 1967, the plaintiff was born there and acquired the

5 As a recent comprehensive work on this point, see Michelle Foster and Hélène Lambert, International Refugee Law and the Protection of Stateless Persons (Oxford University Press 2019).

6 Tokyo High Court, Judgment, Heisei 30 Nen (Gyou-ko) No 232, 29 January 2020, 1-4, 13 16 ('Tokyo High Court, Heisei 30 232').

7 The term 'disposition' refers to acts involving the exercise of public authority by administrative agencies and is the term used in the standard English translation of the Administrative Procedure Act (Act No 88 of 12 November 1993). For such administrative acts, at art 2(2).

8 Minister of Justice, Notification (11 April 2011) (copy on hand with author); Tokyo High Court, Heisei 30 232, 3-5.

9 In addition to the reasons given in the decision at the first instance, the Minister of Justice accepted the opinion of the Refugee Examination Counsellors who doubted the credibility of the applicant's claim: Minister of Justice, Decision (19 September 2014) (copy on hand with author); Tokyo High Court, Heisei 30 232, 4-5.

10 Tokyo District Court, Judgment, Heisei 27 Nen (Gyo-u) No 302, 20 July 2018, 2 ('Tokyo District Court, Heisei 27 302') 5-8.

11 ibid 11-13.

12 Tokyo District Court, Heisei 27 302, 20-28.

13 Tokyo High Court, Heisei 30, 232, 1-5.

14 ibid 8-9.

15 ibid 9.

16 ibid 8. 
nationality of the former Soviet Union. ${ }^{17}$ Until the beginning of 1993, he had his habitual residence in Tbilisi, where he was educated in the Russian language and undertook military service in the former Soviet Union army. ${ }^{18}$

The administration of Georgia at the time of its independence in April 1991 enacted a nationality law that imposed rigid conditions on non-ethnic Georgians who sought to acquire Georgian nationality. ${ }^{19}$ Despite his mother's ethnicity and his limited comprehension of the Armenian language, Georgia considered the plaintiff an ethnic Armenian because of the ethnicity of his father. ${ }^{20}$ Due to the plaintiff's presumed ethnicity and his place of birth, the status of his nationality remained unsettled during the transitional period between the former Soviet Union and Georgian independence. When the former Soviet Union collapsed in December 1991, the plaintiff's nationality of the former Soviet Union ceased to exist, and he was unable to acquire the newly affiliated nationality. ${ }^{21}$

In 1991, the Gamsakhurdia administration of Georgia employed a discriminatory policy to exclude non-Georgians. Many non-Georgians were not protected by the police; rather, they were abused. ${ }^{22}$ Consequently, the nonGeorgian population in Georgia declined precipitously as minorities fled the state. ${ }^{23}$ The plaintiff was also assaulted and robbed in this abusive climate. ${ }^{24}$ The plaintiff could not expect protection from Georgia's police. On the contrary, he feared that the police would harass him. Unable to withstand the situation, he fled Georgia and entered Russia in early 1993. In Russia, the plaintiff was neither permitted to acquire Russian nationality nor become a resident. ${ }^{25}$

As the plaintiff was informed that refugees were more likely to be protected in Germany, he decided to enter Germany via Poland. ${ }^{26}$ After his departure from Russia, he applied for refugee status in Poland, Germany, France, Spain, Norway, Ireland and the United Kingdom. ${ }^{27}$ However, he was either not recognised as a refugee or unable to confirm the outcomes of his applications. ${ }^{28}$ In the United Kingdom, he tried to acquire Russian nationality. ${ }^{29}$ Nevertheless, he was unable to do so as the Russian Embassy requested a certificate that was extremely difficult for him to obtain. ${ }^{30}$ In 2010, after his attempts to receive international protection in Europe failed, he left the United Kingdom with a forged passport, entered Japan and applied for refugee status. ${ }^{31}$

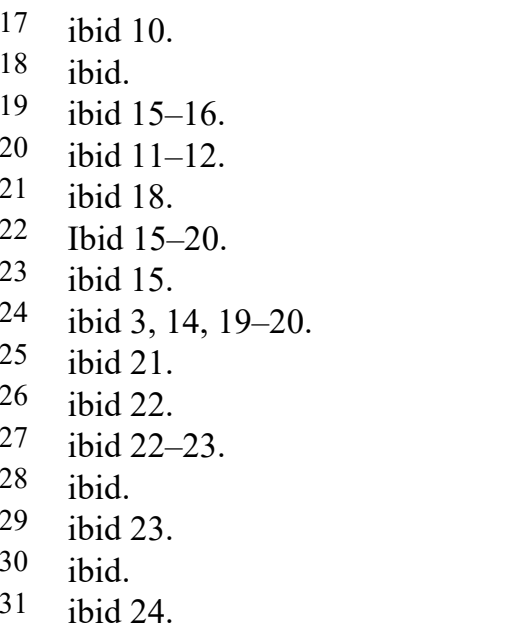




\section{ISSUES}

The issues before the Tokyo High Court included the following: ${ }^{32}$

1. Should the Minister of Justice's disposition that did not recognise the plaintiff as a refugee be revoked?

2. Should the disposition of the deportation order issued by the Tokyo Regional Immigration Bureau be nullified? ${ }^{33}$

3. Should the disposition made by the Tokyo Regional Immigration Bureau that did not grant special permission to stay in Japan be nullified?

Given the widespread interest in statelessness within the ambit of refugee law and international protection, the following parts of this case note deal with the first and the second issues.

\section{HOLDING}

When the Tokyo High Court considered the above-mentioned issues, it looked at three states in relation to the nationality of the plaintiff: the former Soviet Union, Russia and Georgia. Based on the nationality of the plaintiff's family members, the Court confirmed that the plaintiff had held the nationality of the former Soviet Union. ${ }^{34}$ The Court evaluated the circumstance of the plaintiff during the transitional period. It then accepted that after the cessation of the plaintiff's nationality with the former Soviet Union, he acquired the nationality of neither Russia nor Georgia. ${ }^{35}$

Regarding the first issue vis-à-vis the Minister of Justice's disposition that denied recognition of the plaintiff as a refugee, the Tokyo High Court ruled that the disposition should be revoked. ${ }^{36}$ The Court concluded that the plaintiff is a refugee who is a stateless person outside of the state of former habitual residence, Georgia. ${ }^{37}$ The Court examined this issue by assessing the plaintiff's case according to the refugee definition as provided in art 1(A)(2) of the Refugee Convention:

... owing to well-founded fear of being persecuted for reasons of race, religion, nationality, membership of a particular social group or political opinion, is out- side the country of his nationality and is unable or, owing to such fear, is unwilling to avail himself of the protection of that country; or who, not having a nationality and being outside the country of his former habitual residence as a result of such events, is unable or, owing to such fear, is unwilling to return to it. ${ }^{38}$

To assess whether the plaintiff was a refugee, the Court considered the relevant aspects of 'persecution', 'well-founded fear of being persecuted' and the 'Refugee Convention reason' for the persecution. Firstly, on 'persecution', the defendant

32 ibid 1.

33 'Nullify' is the term used in the standard English translation of the Administrative Case Litigation Act to describe an action seeking the declaration of invalidity of an administrative disposition. See Administrative Case Litigation Act (Act No 139 of 16 May 1962) art 3(4).

34 Tokyo High Court, Heisei 30232 (n 6) 25-28.

35 ibid.

36 ibid 30.

37 ibid 29-30.

38 Refugee Convention (n 1) art 1(A)(2). 
argued that the treatment the plaintiff received was not persecution since it did not involve harm to life and body, consistent with a standard metric of persecution in past administrative and judicial practice. ${ }^{39}$ The Tokyo High Court introduced a different analysis from the past general practice in Japan and found that the harm the plaintiff experienced in Georgia was destruction of the basis of his livelihood or subsistence that amounted to persecution. ${ }^{40}$ Secondly, in discussing the element of a 'well-founded fear of being persecuted', the Court pointed out that the government of Georgia still refuses to allow the plaintiff to re-enter its territory and thus, the plaintiff's fear of persecution is continuing at the present moment. ${ }^{41}$ Thirdly, in terms of the 'Refugee Convention reason' for the persecution, it was clear for the Tokyo High Court that the reason was race or ethnicity. The Court considered that having an Armenian ethnicity in Georgia caused persecution and well-founded fear. ${ }^{42}$

With respect to the issue of the nullification of the deportation order, it was a point of dispute whether or not the deportation order could designate Georgia as the destination. Article 53(1) of the Immigration Control and Refugee Recognition Act (1951) provides that any person subject to deportation shall be deported to a state of which they are a national or citizen. ${ }^{43}$ Article 53(2) of the Act follows that if the person cannot be deported to such a state, the person shall be deported to any of the states that art 53(2) lists, for instance, a state in which they once resided, pursuant to their wishes. Because the plaintiff is not 'a national or citizen' of any state and thus, a stateless person, he would be deported to a state pursuant to his wishes.

In the deportation proceedings, the plaintiff consistently expressed that he did not wish to be deported to Georgia where he would face a risk of persecution. ${ }^{4}$ Concerning the interpretation of the phrase 'pursuant to their wishes', the defendant argued that art 53(2) does not prohibit deportation to a state where the concerned person does not wish to go and that the purpose of the article is to take into account the opinion of the person about destination options when repatriation to the state of origin is unfeasible. ${ }^{45}$

The Tokyo High Court concluded that 'the defect of the disposition in this case is significant and evident' and that the entire disposition of the deportation order is nullified. ${ }^{46}$ The Court explained that it is manifestly irrational to designate a state in relation to which the person demonstrates a rational explanation as to why they do not to wish to be deported there. ${ }^{47}$ It thus concluded that the defendant's

39 Tokyo High Court, Heisei 30232 (n 6) 6. The term 'judicial and administrative practices' has been deliberately used in preference to the term 'case law', as there is no consensus if case law is a source of Japanese law and, even if the term is used, the understanding often differs from other jurisdictions.

40 ibid 27-28. See also Part V of this case note. The direct translation of the term used by the Tokyo High Court is 'right to live'. The authors of this note assume that this right derives from the Constitution of Japan (3 November 1946) and was utilised as a concept by the Court in this decision. We have used the terms 'livelihood or subsistence', which is used interchangeably by the Court as the content of that right to avoid confusion.

41 Tokyo High Court, Heisei 30232 (n 6) 28-30.

42 ibid.

43 Immigration Control and Refugee Recognition Act (Cabinet Order No 319 of 4 October 1951).

44 Tokyo High Court, Heisei 30232 (n 6) 24.

45 ibid 7.

46 ibid 31-32.

47 ibid 31. 
decision was contrary to the aim of art 53(2). ${ }^{48}$ It is notable that when concluding its discussion of this issue, the Court gave a warning about the consequences of deporting stateless persons. The Court stated that it had been apparent to the Japanese government that:

[T]he plaintiff is not only a refugee but also a stateless person, and there is an absence of prospective states to accept him; and thus, the plaintiff loses his place on earth when a deportation order is issued. ${ }^{49}$

\section{REASONING}

The judgment of the Tokyo High Court offers a valuable perspective on the Japanese and international jurisprudence concerning protection of stateless persons under the Refugee Convention. In the discussion of the first issue regarding the Minister of Justice's disposition denying recognition of the plaintiff as a refugee, the Court articulated the implications as to how statelessness is related to the terms 'persecution' and 'well-founded fear of being persecuted' in determining refugee status.

First, the Court found that the plight of stateless persons can be perceived as 'persecution' even within the judicial and administrative environment where a rigid and narrow interpretation of the term 'persecution' is generally employed. Regarding the interpretation of persecution, Japanese judicial and administrative practices tend to recognise only violations of freedoms related to physical harm as such, and they hesitate to include violations of other types of freedom, that is to say, economic and social rights. ${ }^{50}$ Yet, stateless persons are often subjected to situations of inequity that can limit their full enjoyment of economic and social rights. ${ }^{51}$ Thus, when this minimalist approach in interpreting the term is employed, the distress that stateless persons face could be entirely dismissed.

In the present judgment, the Tokyo High Court did not intend to alter the established approach for interpreting the term 'persecution'. However, it attempted to link the human rights situation of stateless persons to persecution, even if the term is narrowly defined. The Court implied that the denial of a stateless person's right to property could reach such a serious degree as to amount to persecution when the basis of their livelihood or subsistence is unsecured. ${ }^{52}$

Secondly, it is unique in the jurisprudence of refugee law that the refusal of reentry to a stateless person is discussed in the context of a 'well-founded fear of being persecuted' when evaluating if a harm is ongoing, as it was in this case. The Tokyo High Court understood the past discriminatory policy against nonGeorgians that endangered their livelihoods in Georgia. On the other hand, it found no evidence to support the argument that, in terms of the general human rights situation, non-Georgians are currently facing a risk of systematic and serious harm. However, the Court distinguished the plaintiff's case from others. Presumably the logic of the Court is that, despite termination of the discriminatory policy in Georgia, there is no evidence to support a finding that anti-non-Georgian sentiment has disappeared. The Court presumed that the government of Georgia

48 ibid 30-31.

49 ibid 30.

50 Osamu Arakaki, Refugee Law and Practice in Japan (Ashgate 2008) 165-73.

51 Arakaki (n 4) 78, citing Kate Darling, 'Protection of Stateless Persons in International Asylum and Refugee Law' (2009) 21(4) International Journal of Refugee Law 742, 760-63.

52 Tokyo High Court, Heisei 30232 (n 6) 27. 
may likely exercise extreme wariness towards the plaintiff, who is stateless, given that he does not possess basic ID documents and his identity is unknown. The government could even presume him as a spy from another state. Due to such security concerns, the Georgian government refuses to allow the plaintiff to reenter the state. ${ }^{53}$ This refusal, which firmly denies a foundation for the plaintiff's livelihood or subsistence in the present time, constitutes a continuing, sustained, and serious harm to the plaintiff.

Despite the aforementioned potential contributions to the jurisprudence of refugee law, this judgment has several limitations. Firstly, although elements of statelessness are heavily involved in this court case, the Tokyo High Court did not clarify who may be considered a stateless person. While Japan is not a party to the 1954 Convention, the Court should have employed the definition of a stateless person set out in that Convention as a first step in its discussion of this case, as the definition has acquired a customary nature. Secondly, the Court has not explored the meaning of other important terms such as 'country of former habitual residence' provided in the Refugee Convention.

\section{CONCLUSION}

It is worth stressing that the Tokyo High Court in this judgment demonstrated the possibility that the hardship of stateless persons can be linked to the term 'persecution' even within an administrative or judicial environment where the term is restrictively interpreted as harm to life and body. More remarkably, the judgment has added to the jurisprudence on the idea that the attitude of the state of former habitual residence in refusing re-entry to a stateless person can be evidence of a continuing and sustained harm regarding a 'well-founded fear of being persecuted'. It is hoped that in the future, Japanese courts will set out a fundamental framework in which the statelessness factor is comprehensively analysed in the context of refugee protection.

53 ibid 28. 